\title{
Challenges for Industrialisation in India: State versus Market Policies
}

\author{
Kalim Siddiqui $^{1}$ \\ ${ }^{1}$ The Business School, University of Huddersfield, Queensgate, Huddersfield, UK \\ Correspondence: Dr. Kalim Siddiqui, The Business School, University of Huddersfield, Queensgate, Huddersfield, \\ HD1 3DG, UK. E-mail: k.u.siddiqui@hud.ac.uk
}

Received: May 15, 2015

doi:10.5430/rwe.v6n2p85
Accepted: June 10, 2015

Online Published: June 18, 2015

URL: http://dx.doi.org/10.5430/rwe.v6n2p85

\begin{abstract}
The study is important because there currently seems to be a gap in the literature, since most published research has highlighted India's overall GDP growth rates. Little academic research has been done on the importance and performance of industrial sectors in a developing economy like that of India. The industrial sector there has languished at around $16 \%$ of GDP, which is much less than that of China or of any other country at India's stage of economic development.

The neoliberal reforms of 1991 in India removed tariffs and barriers to foreign trade and investment. India reduced the role of state and public sector, and dismantled controls, while increasing the role of the market and private sector within the economy. As a result, foreign capital investment and foreign exchange reserves improved. However, job expansion did not occur and there has been no corresponding decline in the share in agricultural employment. Even the much heralded IT sector's dramatic expansion over the last two decades has provided jobs directly to less than a million people.

This study argues that it would be misleading to think that a large country like India could industrialise and modernise its economy whilst the unequal distribution of land and rural assets, and the dismal performance of the agricultural sector remains. This study concludes that more than two decades have passed since the neoliberal reforms were launched, but industrial growth has still not witnessed rapid expansion, especially in manufacturing areas. It seems, then, that neoliberal policies have failed to create jobs and thus improve the living conditions of a significant proportion of the population.
\end{abstract}

Keywords: Indian economy, manufacturing sector, and economic liberalisation

\section{Introduction}

The global economy has witnessed tremendous changes over the course of the last few decades with the developed countries having witnessed de-industrialisation i.e. the decline of the relative importance of manufacturing in terms of output, revenue generation and employment.

For a heavily populated country such as India, the manufacturing sector still seems to be the only path which the traditional economy can take in order to secure better living conditions for the people. Therefore, industrialisation is seen as being crucial to transforming a backward economy with low productivity. By this, we do not mean to suggest that the solution lies in the type of industrialisation that is likely to create environmental and ecological crisis. However, a discussion concerning the type of industry lies outside the scope of this study.

The main purpose of this paper is to examine the growth and importance of the industrial sector in India. There seems to be a gap in the literature because most research has chosen to highlight the overall GDP growth rates of the Indian economy (Basu and Maertens, 2007; Srinivasan, 2005), but little has been written about the industrial sector's importance, performance and near stagnation in overall job creation since economic reforms were launched in 1991. India's industrial sector has languished at around 16\% of GDP, which is much less than that of China or any other country at India's stage of economic development.

The balance of payments crisis in 1991 took place after nearly a decade of stable economic performance i.e. lower inflation rates and some improvements in growth performance. In fact, these reforms had been preceded by pro-business reforms and India had borrowed from the IMF after the second oil shock. Economic reforms continued and by the mid-1980s further steps had been taken to de-regulate industry and trade. Economic liberalisation 
involves adopting more open trade and capital accounts policies. High output growth and very little or negligible employment growth is a feature of the economy under neoliberal policies in India. Even stagnating or falling real wages, along with falling wage shares have not moved towards increased labour demand in the manufacturing sector (Nayyar, 2006).

India has moved from a mixed economy, despite the fact that the private sector was much larger than public sector, but the government exercised a large degree of control via "license raj" to a less regulated and more open economy with the private sector designed to play a more significant role than the public sector. India's engagement with the global economy has increased rapidly in recent decades. Despite all these stimuli, the options for industrialisation began to be exhausted by the mid-1970s and the big industrialists saw that only collaborations and joint ventures, along with the availability of foreign borrowing and foreign markets, could further their interests. In addition, some high tech and IT companies found their interests lay with increased global market integration and gaining more access to foreign technology to improve efficiency and productivity, and enhance their growth. All these domestic changes led to the launching of neoliberal reforms, which began in the early 1980s and with major large-scale policy change in 1991 (Siddiqui, 1991). Industries in India tend to be dominated by a large number of small enterprises and a few large companies.

Since economic reforms in 1991, India has experienced rapid growth in the service sector without going through the intermediate phase of a significant expansion of the manufacturing sector. The aims of the neoliberal policies adopted in 1991 were mainly: to remove the capital control on production, prices and market forces to influence investment and operational decisions; to allow international prices and market competition to influence economic decisions; and to liberalise the financial sector and remove controls over the banking sector (such as reducing state-directed credits and freeing the interest rates); and finally, to privatise public assets. Liberalisation of trade and investment rules was relaxed in India in 1991 to attract foreign capital and investment, and it was hoped that such changes would be able to attract relevant sectors to India from global value chain production, which increasingly serve as a location for world market production; however, there had been little success to date (Nayyar, 2006).

Indian economic growth reveals that this growth is unbalanced in terms of sector i.e. for nearly a quarter of a century services have grown much faster than other sectors in the economy. Growth in the industrial and agricultural sector, which provides jobs for the majority of the work force, has been slower. Despite high growth rates annually of more than 7\%, developing economies such as India experienced a slight fall in their share of industry between 1998 and 2010. Their share of agriculture also continued to fall, while the service sector has expanded sharply since the early 1990s (Siddiqui, 2014a).

Despite experiencing faster economic growth for over two decades, this has not created enough opportunity for the people working in agriculture to move out and find jobs in the industrial sector. This is because the industrial sector in India has experienced slow growth in employment i.e. less than $1 \%$ per annum. This structurally uneven growth, coupled with disproportionate policy and economic interventions, has led to the emergence of inter-sectoral differences, marked by agrarian crisis and slow industrialisation (Siddiqui, 2014a).

In 2013 , nearly $60 \%$ of total employment was still in the agricultural sector, with productivity levels which generated incomes which were less than one-fifth of those in the rest of the economy (Economic Survey, 2014). Highly productive agriculture cannot employ huge number of people. Therefore, the development of the manufacturing sector is essential for productivity growth and for the realisation of learning by doing and increasing returns associated with new processes and product differentiation.

Despite the rapid growth India has made since reforms, in terms of employment it still remains primarily an agricultural economy, accounting for nearly two-thirds of total employment and a fifth of the country's GDP. Between 1983 and 1993, employment increased by more than 2\% per annum. Then, from 1994 to 2006, the economy grew faster but employment growth decreased to $1.8 \%$ per annum. Since 2006 matters have become worse in terms of employment growth. Employment elasticity, which is a measure of the jobs that economic growth produces, had been $0.44 \%$ between 1999 and 2005, while it declined to $0.01 \%$ for the period from 2005 to 2012 (Siddiqui, 2014a).

For a meaningful understanding of the performance of the industrial sector in India, we must look at historical perspectives to compare this with past performance. According to the statistics, during the pre-reform period between 1950 and 1960, the growth rate in the industrial sector was 6.1\% per annum, which declined to an average of $4.8 \%$ between 1960 and 1980. However, it increased to 8.2\% per annum between 1980 and 1990 (CSO, 2014). Despite post-reform period (1992-2012), industrial growth increased to an average of around 7\% for India, while this figure was $11 \%$ for China for the same period per annum. 
This article is organised as following. Following the introduction to this topic in section I, section II is briefly discusses the theoretical significance of the industrial sector. Section III analyses the relationship between agriculture and the industrial sector whilst sections IV and V focus on industrial growth during the pre-and post-Independence periods. Section VI then examines state vs. market policies, followed by a conclusion which summarises the findings.

At present, the manufacturing sector contributes nearly $16 \%$ to India's GDP, provides jobs to $10 \%$ of the country's total workforce and produces nearly $80 \%$ of its total merchandise exports. Although manufacturing sector is relatively small in comparison to India's whole economy, but this sector could play an important role in raising the productivity and in its development efforts.

India's policy makers have tended to focus largely on GDP growth and overlooked the fact that the economy needs to create more jobs. When India has the largest number of young people of any country in the world, merely providing them with education is not enough. We need to find the real constraints on the growth of enterprises.

Between 1900 and 1946, primary sector growth was $0.9 \%$, while the secondary sector growth was only $1.1 \%$ (Maddison, 1995). In contrast, from 1950 to 2013, the primary sector in India grew at an average of 2.2\% per annum, and the secondary sector at $5.3 \%$. Looking at individual decades, growth in the secondary sector was $6.7 \%$ in 1980-1990, and while it slowed down somewhat in the post-reform period (1991-2013), the secondary sector still grew at an average of $6 \%$ per annum (CSO, 2014). The past decades in India appear to have witnessed inadequate diversification of India's production structure away from agriculture and into manufacturing and somewhat premature rapid diversification into the service sector, (Siddiqui, 2015a).

The methodology to be followed here is derived from the aims of the study and comparisons of international statistics provide the main means of addressing the research questions and the objectives of this paper. Analysing pre-existing secondary data is the only possible way to obtain macroeconomic data. These include data from official sources and from international institutions such as the World Bank and UNCTAD.

\section{Theoretical Significance}

The term 'industrialisation' refers to the shift in the pattern of a country's output and workforce towards industry. The industrial sector becomes proportionally more import than the primary sector both in terms of employment and revenue generation. Furthermore, industrialisation seems to be very important in order to achieve affluence. Past experiences of developed countries suggest that to become prosperous a country needed to swing heavily towards expansion of manufacturing (Patnaik, 1979; Raj, 1986).

According to Kaldor, industrialisation is a necessary stage of development, since it represents the development of productive forces and technology. In the developing countries industrialisation can play an important role as it saves foreign exchange by reducing imports and expanding employment opportunities; it lessens the burden on the agricultural sector, and also raises the overall productivity in the economy. The successful experiences of the industrialised countries also indicate that their success had been largely due to their strong manufacturing sector. As Kaldor observes that "The kind of economic growth which involves the use of modern technologies, and which eventuates in high real income per capita is inconceivable without industrialisation" (Kaldor, 1967:54).

The growth of industry appears to be very important to the economic growth and well-being of the population of developing countries such as India. Kaldor (1967) identified what he considered to be the most critical issues in his 'Laws of Economic Development'. He sees the wider impact of the manufacturing sector as follows: 1) Higher growth in the manufacturing sectors could also lead to an increase in labour productivity; 2) Productivity in the non-manufacturing sector increases as the manufacturing sector expands; 3) Manufacturing is an engine of growth, not only because of higher productivity but also because of the external economies it generates, including forward and backward linkages; 4) As the manufacturing sector expands it provides job opportunities for the surplus labour in the agricultural sector, which ultimately reduces levels of unemployment and poverty (Kaldor, 1967). Job creation in manufacturing is related to the rate of growth of the output or value added. This, in turn, is linked with the rate of growth of wages relative to value added. Kalecki (1971) referred to the 'mark-up price' above the costs which the producers are able to charge or to the 'degree of monopoly' in the market.

Industrialisation is important but the identity of the central actor driving the industrialisation process is also equally important. Past experiences of a number of countries show that industrialisation is not merely an instrument of economic growth but also has an in-built mechanism for distributing the costs and benefits of growth. However, it seems that the opening up of domestic markets and free trade as strategies for industrialisation can be incompatible with the circumstances, particularly for late-industrialising countries. For example, South Korea is characterised by active state intervention in the economy and the accumulation process was sustained (Amsden, 2003). Protection for 
certain strategic industries by the state in South Korea was considered necessary in order to bring about a situation where integration with the world economy would lead to the development of industries and expansion in employment domestically.

During the last four decades, the rapid economic transformation of the East Asian countries has become the most important development in the world economy. For instance, initially the development in Japan, then South Korea and most recently in China has been the most spectacular and the most widely discussed (Siddiqui, 2009; Das, 2006). However, proponents of 'outward-looking' industrialisation policy overlook the differences among the East Asian countries that successfully followed this policy (Siddiqui, 2013). Japan and South Korea had almost no foreign direct investment capital flows, while the economies of East Asian countries like Hong Kong, Singapore (Siddiqui, 2010) and more recently, China, have been dominated by inflows of foreign capital (Sen, 2007).

Currently, China and India are among the fastest growing economies in the world. Despite the differences in the performance of the industrial sectors in both countries, industry could have a vital role to play in improving the economy, productivity and living conditions of their people. These two countries together constitute nearly $40 \%$ of the world's population. Therefore, what happens to China and India is of great importance to academics and policy makers (Siddiqui, 2009).Manufacturing activities can be regarded as a critical engine of growth for the economy. The development of the manufacturing sector is seen to be crucial in order to allow India to expand supply and reduce the risk that the current growth spurt might not be sustainable because of supply side constraints (The Economist, 2007).

\section{Relationship between Agriculture and Industry}

Industry and agriculture are closely inter-related, as the performance of one sector affects that of the other. The agricultural sector provides raw materials for industries and also offers an important market for locally produced manufacturing goods (Siddiqui, 2015a). Earlier discussion of the relationship between industrialisation and agriculture by Prebisch, Lewis and others focused on agricultural growth as a very important stimulus towards rapid industrialisation through transfer of savings. Lewis (1954) emphasised that the agricultural sector plays an important role as a supplier of surplus to industry. He suggested that the supply of surplus from the agricultural sector and also a constant supply of workers at low wages could be important factors towards industrial growth. Lewis (1954) argues that: "Industrialisation is dependent upon agricultural improvement; it is not profitable to produce a growing volume of manufactures unless agricultural production is growing simultaneously. This is also why industrial and agrarian revolutions always go together. Economies in which, agriculture is stagnant do not show industrial development" (Lewis, 1954:433).

Demand-side constraints and how these might impact on the demand for industrial product in the domestic market was another major issue. Kaldor (1967) focused specifically on the demand-side problem of industrial growth. According to him, the growth of agricultural surplus is an essential condition to raise the purchasing power necessary for sustaining industrial growth. Kaldor suggests that to sustain industrialisation the terms of trade between these two sectors should be in favour of agriculture. He further argues that agricultural productivity should be improved with the help of technology to increase surplus and that would keep the food prices low, while increasing the demand for industrial goods (Kaldor, 1967).

The Prebisch-Singer model emphasises that elasticity is generally greater for manufacturing than primary products. Prior to industrialisation a country obviously had to resort to importing industrial goods and exporting primary goods. Prebisch-Singer OR Prebisch and Singer also noted that the terms of trade in the past had often been against the interests of primary producers, meaning that under such circumstances a country's imports of industrial goods would be limited by its export earnings (Siddiqui, 1998). Thus, the dependence on importing industrial goods and modern technology would limit the possibilities of income growth. Under such circumstances, an import substitution policy would help the country to relax these constraints by economising on the use of foreign exchange (Singer, 1987).

Moreover, the financing of the investment required by industries could be done by transferring funds from the agricultural sector. The terms of trade were favourable in the agricultural sector in India, especially in the period from the 1960s to the 1980s, but the outcome was that neither the industrial sector nor the rural poor benefitted from this. The Indian government refused to tax rich farmers and large land owners to raise revenue. As a result, the rural rich siphoned off most of the surplus, since they did not pay any direct taxation and deprived the rural poor by undermining land reforms and not implementing minimum wages (Siddiqui, 2015a).

It appears that in the absence of significant improvement in the rates of growth in agriculture, in the near future there will be greater willingness to use imports to dampen down rising prices and place constraints on the supply of raw materials. K. N. Raj has commented: "Private consumers demand in a country such as India depends to a large extent 
[...] on how things go in the agricultural sector. If output and income in this sector are rising rapidly, consumer demand for both agriculture and non-agricultural product can also be expected to increase rapidly, the latter being even more than the former since higher proportions are generally spent on non-agricultural products as levels of income rise (Raj, 1986: 225).

\section{Industrialisation during the Colonial Period: 1757-1947}

During the colonial period, modern industrial development in India was only carried out by the private sector because state investment in the industrial sector was dismal (Siddiqui, 1996). Academics have already discussed the $19^{\text {th }}$ century impact of the British rule on Indian industry, especially the decline of the indigenous handicraft manufacturing sector (Dutt, 1902; Anstey, 1957; Thorner, 1962; Siddiqui, 1990). However, the neoclassical economists choose to ignore past economic realities, failing to say anything about how a handful of metropolitan countries controlled global resources and created a new international division of labour to further their economic and strategic interests (Chang, 2010; Reinert, 2007; Siddiqui, 1990).

British rule in India lasted for nearly 200 years. In terms of policies, it could be divided into three phases. The British's own class forces changed which led to changes in policies in India. The first phase (1757-1813) could be termed as the merchant capital period. During this period, merchants enjoyed monopoly trade between India and Europe, dominated by the 'East India Company', a British trading company based in the City of London. During the second phase (1813-1890), the trade monopoly of the 'East India Company' was abolished and policies in India were enacted to promote British industrial capital. In the third phase (1890-1946) was led by the interest of the finance capital and it was dominated by the export of capital from Britain to India for mining, tea plantations, railways etc. During this period British investment in India was one-sided and did not stimulate overall industrial growth in India. Moreover, vast funds were spent for unproductive purposes such as the military, colonial administration, etc. while productive activity was confined largely to the extraction of raw materials. Even the banks and insurance companies were developed to stimulate the production of raw materials (Siddiqui, 1990:65).

The primary method of surplus extraction in India was in the form of land revenue levies. Initially the East India Company's trade was based on the import of Indian piece goods (such as muslin and calico), spices, indigo and silk. The trade was financed by the export of Treasury bullion from Britain. However, after the occupation of Bengal, the Company gained ultimate control of resources beyond their wildest dreams which they were able to exploit without having to pay but were able to sell at full price. This could be achieved by treating the entire revenue of India as gross profit (Bagchi, 1976). As Habib (1984) argues, following the Plassey victory in 1757 i.e. occupation of Bengal: "enormous individual fortunes were made, $[\ldots]$ followed by a continuous extraction of wealth, through taxation, monopoly and corruption" (Habib, 1984: 5).

The benefits that the industrialised countries derived from their colonial markets are ignored in neo-classical arguments (Krueger, 1987). The Colonies provided markets, supplied raw materials and cheap labour. The economic policies were formulated in the Colonies to suit the metropolis. For Britain, for example, the access to colonial markets provided assured markets for their manufactured goods but at the same time British protectionism ensured that Indian manufactured goods could not be sold into British markets (Siddiqui, 1990). The supply of cheap raw materials from India minimised inflation in Britain. Until the end of the $19^{\text {th }}$ century, nearly half of British exports consisted of cotton textiles, destined chiefly for India and China, ironically at the same time that these two countries were themselves experiencing de-industrialisation, massive unemployment and poverty (Siddiqui, 2009). The international division of labour was created with the metropolis producing manufactured and exported high-end goods while the Colonies served as a source of raw materials and primary commodities.

For the Colonies, the notion of 'comparative advantage' meant that they had to specialise in the production and export of raw materials. In fact, the adoption of such policies led to the perpetuation of mass poverty and famine in India for the whole of the $19^{\text {th }}$ century and first half of the $20^{\text {th }}$. India proved to be useful to Britain as the surplus extracted from this colony was used to settle its deficits with the other industrialised countries whose goods it had imported. During the period from 1900 to 1946, India experienced near stagnation in per capita income, while GDP growth was minimal. Maddison estimated that growth in national output was only $0.81 \%$ per annum, whereas growth in per capita was dismal, being just $0.04 \%$ per annum (Maddison, 1995). In contrast to this, in the second half of the $20^{\text {th }}$ century the annual growth in GDP was $4.2 \%$ and per capita income was $2.1 \%$.

Thorner (1962) analysed the issue of the destruction of handicrafts in India. He defined de-industrialisation as either a decline in the proportion of the working population engaged in the industrial sector or a decline in the proportion of the total population dependent on the industrial sector. Thorner argues: "India's national handicrafts have declined sadly from their pristine glory. This falling-off, however, was not a phenomenon peculiar to India but a worldwide 
development affecting countries at different times. The ruin sooner or later of the old style craftsmen, was an integral part of the Industrial Revolution as the coming of the factory system" (Thorner, 1962: 70).

However, it seems that such an argument ignores that industrial development in Britain as a colonising power and India as a colonised country had taken place in different circumstances. For example, in Britain, the traditional industries such as handicrafts faced destruction in the $19^{\text {th }}$ century due to the rapid development of industries. People lost jobs in the traditional industries but the jobs created in the modern industries were much higher than those which were lost. However, the experience in the Colonies such as India was quite different. The British government used protective measures not only during the early years of the Industrial Revolution but right the way through until the 1840s; however, no such protective measures were available for Indian industries. In India, handloom weaving and hand-spinning constituted the largest handicraft industries, employing a large number of people. Therefore, their destruction had a very depressive effect on the whole economy (Siddiqui, 1996; Bagchi, 1985; Habib, 1975). As Bagchi (1976: 154) observes: "Within India herself, when de-industrialisation drove labourers to seek their living in agriculture, they faced highly imperfect market, the most important complementary asset, land, being already concentrated in the hands of landlords".

The growth of the British textile industry practically wiped out India's cotton goods markets in Britain, and even began to seriously threaten Indian industries in their home markets. For instance, Britain's textile goods exports rose from 0.8 million yards in 1815 to 45,000 million yards in 1830; this increased again to 51.78 million yards in 1835 and had reached 100,000 million yards by 1839. Cotton twist increased from just 8 IBs in 1814 to 4.56 IBs in 1828 and 10.81 million IBs by 1839. In terms of monetary value, Britain’s total cotton exports to India amounted to £2.29 million in 1839 whilst cotton twist was another $£ 0.64$ million. But by 1855 these figures had risen to $£ 5.40$ million and $£ 1.27$ million, while India's manufactured cotton exports declined. For example, between 1794 and 1804 India's piece goods exports were $£ 2.42$ million per annum. Later, this figure fell sharply to $£ 0.69$ million by 1849 (Anstey, 1957; Dutt, 1902). Similar trends could be seen in other areas of Britain's exports to Indian markets with iron bars, machinery, bolts, cutlery, guns, and glasses all having rapidly increased. This led to the 'de-industrialisation' of India. As Habib argues that "The urban decline, initiated by the diversion of surplus from the Indian ruling classes to the Company, spread quite naturally wherever the East India Company's sovereignty extended. It was compounded many times over the urban unemployment by English manufacturers. This urban decline seems not only to have been in relative terms (percentage of urban population to total), but in absolute terms as well" (Habib, 1975: 38).

The surplus was not invested domestically in India and did not create new jobs. As a result the Indian economy became subservient rather than sovereign in terms of policy matters. The fruits of its labour were systematically transferred to Britain or its new colonies of white settlers. Economic development was hampered by the removal of 'surplus', high land rents and tribute charges, and also by the destruction of the Indian capitalist class meaning that they were unable to invest. A densely populated country like India was drawn into the orbit of exploitation in the mid- $18^{\text {th }}$ century and later on, in the interest of British industry, India was utilised as a huge market for their products. Moreover, as Bagchi (1985) argues: "Competition from the foreign cloth led to the unemployment among handloom weaver, where wages declined" (Bagchi, 1985: 101). The huge increase in the cultivation of the opium, indigo, tea and jute led to the decline of land available for the cultivation of food crops. As Bagchi notes about the changes in the production structure that, "The trade in opium illustrates how advanced capitalist countries have in the past moulded the production and consumption structure of the whole subcontinents and have impeded their progress" (Bagchi, 1985: 102).

\section{Industrial Performance from 1947 to 1990}

On the eve of independence in 1947 modern large scale industries and mining contributed just 7\% of India's GDP, while small scale industries accounted for $10 \%$ and the agricultural sector $49 \%$ and services and construction $34 \%$. Total employment in the industrial sector was just 2.9 million people, which amounted to less than $2 \%$ of the total workforce. In contrast to this, the small industries employed a much higher proportion, some $7 \%$ of the workforce, while nearly $72 \%$ of the Indian workforce was employed in agriculture; services including construction employed $18.7 \%$ of the total workforce. Cotton and jute were among the main modern industries established in the early $20^{\text {th }}$ century in India (Siddiqui, 1996).

In fact, even this lop-sided industrialisation that India had managed to achieve under colonial rule was closely linked to British industrial and financial interest rather than sovereign industrial growth (Patnaik, 1979). The anti-colonial struggle in India had a clear vision concerning the need for improvement in the material conditions of life of the people. Post-independence India the state played an active role, which was seen as beneficial by the industrialists who came up with 'Bombay Plan', which suggested that public investment was needed in key industrial sectors to boost the economy. The policy was aimed at developing basic industries via government planning, while the bulk of 
the economy remained in the hands of private enterprises. India's first Prime Minister, Nehru, was impressed with Soviet economic planning and the USSR's rapid capital intensive industrialisation. It was said that such strategy posed a constraint on resources available for agricultural development. For example, government spending on agriculture and irrigation decreased from $34.6 \%$ in the first Five-Year Plan to $17.5 \%$ in the second Five-Year Plan, with investment in heavy industries being prioritised during this later period. The second Five-Year Plan in 1956 was launched to build 'heavy industries', which was seen as being essential for the country's long term industrial growth.

The "inward-looking" dirigiste economic strategy adopted in pre-reform period in India was seen as the most suitable option by the ruling elites. Also known as the 'import substitution' strategy option the public sector was expected to take a leading role in the development process. However, such policies were criticised by neoclassical economists as inefficient, promoting delays and corruption (Srinivasan, 20005). The proponents of neo-liberal reforms argue that: "Rather than adopting the classic Asian strategy -exporting labour-intensive low-priced manufactured goods to the West- India has relied on its domestic market more than exports, consumption more than investment, services more than industry, and high-tech more than low-skilled manufacturing" (Das, 2006:2).The aim was to remove serious gaps in the production structure. Due to the long gestation period, private investors saw such investments as high risk and also lacked funds (Patnaik, 1979).

On the other hand, the government was determined not to tax the rich. Therefore, for public sector investment funding, the government relied on foreign aid, deficit financing and indirect taxation. As a result, for example, the share of indirect taxes to the total tax revenue increased from $61.9 \%$ in 1955 to $70.7 \%$ in 1966 . Both indirect taxes and deficit financing were regressive, meaning that they had a dampening effect on income for the majority of people. As a result, the domestic market for mass consumer goods did not increase. Hence, further initiatives for investment and industrialisation by private investors were undermined (Raj, 1986).

Between 1951 and 1965, the annual average industrial growth was 7\%, which was much higher than anything that had been seen in the past. There was also a notable shift as the importance of traditional industries such as jute and cotton declined, while modern industries such as machinery, engineering, chemicals, rubber, pharmaceuticals, power and steel became more important. However, the industrial growth also coincided with huge increments in foreign debts and foreign aid, which meant that industrialisation in India was not financially self-reliant. Moreover, Indian industries did not allocate much money for research and development, which resulted in increased reliance on imported technology and foreign corporations. Although pre-reform industrialisation in India was impressive in terms of growth, it failed to make any dent on growing unemployment (Raj, 1986).

Industrial stagnation marked the period from the mid-1960s to the end of the 1970s. Then in the early 1980s, the government took various measures to promote businesses and as a result the economy grew faster in comparison to previous decades, but the country relied heavily on foreign borrowings. The fiscal deficit and foreign debts had increased to high levels by the end of the 1980s. As a result, the debt service ratio had become untenable.

\section{Economic Reforms of 1991 and Industrial Growth}

In 1991, the Gulf War added to the fiscal crisis and a further crisis was just waiting to happen. The Congress government decided to accept an IMF loan and under the Finance Minister, Manmohan Singh, it began to implement neoliberal economic reforms. As a result, industrial licensing was discarded and import tariff rates were sharply reduced. The IMF and World Bank supported neoliberal reforms since the role of the state in the economy would be very limited. The product markets were liberalised and there was also a shift from 'import substitution' to 'export-oriented' policies (Bhaduri, 1993). During the early 1990s, the Indian economy rapidly opened up. It seems that this was done not only to enforce a cost discipline on the supply side through foreign competition, but also to narrow the differences between domestic and international prices.

The key question arises: What has happened to industrial growth since the economic reforms were undertaken in 1991 in India? After two years of negative growth, growth rates began to increase in 1994. The annual growth rate in the manufacturing sector was $6.4 \%$, which was lower than that during the $1980 \mathrm{~s}$, namely $8.2 \%$. In manufacturing, various industries behaved differently. For instance, consumer durable goods continued to grow fastest but the capital goods industry suffered most. As a result, the annual growth rate of electrical goods declined by nearly $6.7 \%$ between 1991 and 1999. This was not due to a fall in the investment rate but because of increasing import competition, as tariff on imports were substantially reduced during this period.

India's foreign exchange balance started to rise from a very low level in 1991, when the economy was at very critical level. Exports have risen, especially in software and information-related technology. Exports as a percentage of GDP exceeded 10\% for the first time in 1992 and then remained at around 19\%. There was success in both the software and the pharmaceuticals sector and Indian corporations also invested overseas in buying international companies. 
Since 2007, a number of Indian companies (such as Tata, Hindalco etc.) went for acquisition in the United States and various European countries on the strength of massive foreign currency loans at low costs.

Panagariya (2004) argues that the surge in industrial growth in India which took place in the 1980s could not be attributed entirely to the economic reforms of 1991. The 1980s industrial policies could not be sustained over a longer period, as they relied on huge deficit financing and excessive foreign borrowings. According to Basu and Maertens (2007) argue that, "If India wants to sustain and raise even higher its current growth, the main bottlenecks in the Indian economy will need to be addressed. These are infrastructuressuch as roads, expensive freight rates, power supply, ports and airports, labour and bankruptcy regulations, and the high level of corruption" (Basu and Maertens, 2007: 164).

With regard to the comparison between the manufacturing sector performance in the pre-and post-reform period, Nagaraj (2006) noted: "The growth rates for the period before reforms (1980-81 and 1991-92) are 7.4\% and 7.6\% per year respectively[...] However, there are no statistically significant changes in the trend growth rate of the registered manufacturing GDP after reforms" (Nagaraj, 2006: 180).

The Economic Survey 2014 states that growth is the prerequisite for achieving several economic objectives including economic development, industrialisation and improving the living conditions of ordinary people. Prior to economic liberalisation, domestic savings were mobilised and invested in the public sector, which relied on domestic markets. But since the adoption of economic reforms, hopes have been pinned upon foreign capital and MNCs to achieve modernisation and productivity growth. However, growing trade deficits in the manufacturing sector clearly show that the manufacturing sector is losing its competitiveness across the range of medium- to high-tech goods. Manufacturing of this kind accounted for only 15\% of India's export earnings in 2010 as against a corresponding figure of 50\% for China (UNCTAD, 2013: 173) whilst resource- and knowledge-based exports account for 25\% of India's total export earnings.

In terms of ownership, industries in India have been largely owned and controlled by families as monopolies rather than having to face a competitive environment. These family-owned big businesses had long been operating in a non-competitive environment.

It has been claimed that an increase in the rate of investment necessarily increases the rate of growth of aggregate supply of goods and services (Srinivasan, 2005). But if there is no mechanism in the economy which can generate a corresponding and equivalent growth in aggregate demand, then an increase in the rate of growth in the economy would lead to an increase in unsold goods and services. The intersectoral shift in the workforce from agriculture to manufacturing slowed down during the period 1990 to 1997 and labour productivity in the non-agricultural sector (including manufacturing and services) was nearly four times that in agriculture. It clearly means that this slow-down in the transformation of the workforce implies an immense loss in productivity gains. To regain this loss of momentum in workforce transformation and to ensure better utilisation of surplus labour is crucial, lying at the heart of equity growth in a large agrarian country such as India.

India's experience over the past few decades indicates that corporations are out to make profits by cutting costs, especially the cost of labour. They create more output per worker but not much employment. For example, Tata Steel in Jamshedpur increased its annual production five-fold from 1 million to 5 million tonnes between 1991 and 2006, but at the same time it reduced its workforce from 85,000 to 44,000. Similarly, India's record of employment generation has been dismal for over two decades under neoliberal reforms. Despite an annual GDP growth rate of over $7 \%$, growth in employment has been less than $1 \%$.

Moreover, it was expected that an open economy would lead to the availability of cheaper capital goods and machinery, and ultimately would result in the expansion of labour intensive industries, but this did not happen. The crucial point is whether the neoclassical model provides an adequate framework to understand the development process of a huge agrarian country such as India. As Bhaduri argues that, "In the presence of substantially under-utilised labour, an extensive growth strategy may still form an essential element in the early phase of development process [...] indeed there is something strange about so much attention being paid to "efficient allocation of resources' and the price mechanism while ignoring the blatant inefficiency of massive under-employment" (Bhaduri, 1993: 11).

The neoclassical model pretends that the benefits of higher growth 'trickle down' to the poor. However, not only is this proposition empirically dubious but the time period for this to happen remains unspecified. It seems increasingly clear that the government views its role as being that of promoting the corporate sector rather than regulating between businesses and the people. 
It seems that the current vision is not even pro-market, but blatantly pro-corporate sector. Of course, markets and corporations are important, but underestimating the role of government as neoclassical economists suggest would be troublesome (Srinivasan, 2005). The role of government is to reconcile the demands of various business sectors with those of the rest of society. In fact, the industrialised countries advanced in technology and productivity not by means of the pursuit of free-market and neoliberal policies as neoclassical economists claim, but by conscious policy efforts to promote their businesses and strategic interests (Bhaduri, 1993).

Some Indian companies welcomed foreign capital and technology. The IT sector which is highly competitive found their interests would be better served by closer cooperation with global markets. Some small and medium enterprises also welcomed this as they found thatthe foreign technologies, capital and business organisation in addition to joint ventures with foreign companies would help them to compete with domestic monopolies. For example, increasing the foreign equity limit in Indian telecommunications was supported by Bharti Enterprises, as it helped the company to enter into a successful partnership with Signtel, Warburg Pincus and other overseas companies. India's largest companies also found new opportunities to enter the global market. For example, Tata valued at US\$ 70 billion in 2012, has transformed itself into an Indian multinational company. Its global sales for 2010 represented more than two-third of its total sales and one-third of its total employees work outside India.

New industrial policies were designed along the lines of pro-market reforms, in order to give huge subsidies and concessions to the corporate sector, including foreign investors, rather than raising income and employment for the poor in India (Siddiqui, 2014b). The government has not paid much attention in recent decades to demand-side constraints, mainly focusing on supply-side constraints to alter the slow rate of industrialisation on the recommendations of the IMF and World Bank (World Bank, 2006).

We should not ignore the changing nature of the composition of both Indian and foreign markets. The reasons for the slow growth of industries could also explain lack of job creation. The sectoral shift in favour of services and economic liberalisation means the further opening up of Indian markets has led to the increase in imports of goods especially for the richer sections of society. Increased reliance on exports would mean Indian industries have to produce goods that are in demand on the world market, manufactured using modern technology, which is often labour-saving. Increasing reliance on MNCs, which employ capital saving technology and high import intensity of domestic manufacturing, reduces the employment elasticity of growth.

On the question of inter-sectoral growth rates, as Figure 1 shows, growth rates in the non- agricultural sector were faster than those in the agricultural sector between 1997 and 2011. However, within the non-agricultural sector, the service sector has been growing much faster than the manufacturing sector. In 2008, the manufacturing sector grew at higher rates, but again declined by nearly half in 2008, slightly recovering in 2010, but then decreasing again to just $4 \%$ in 2011.

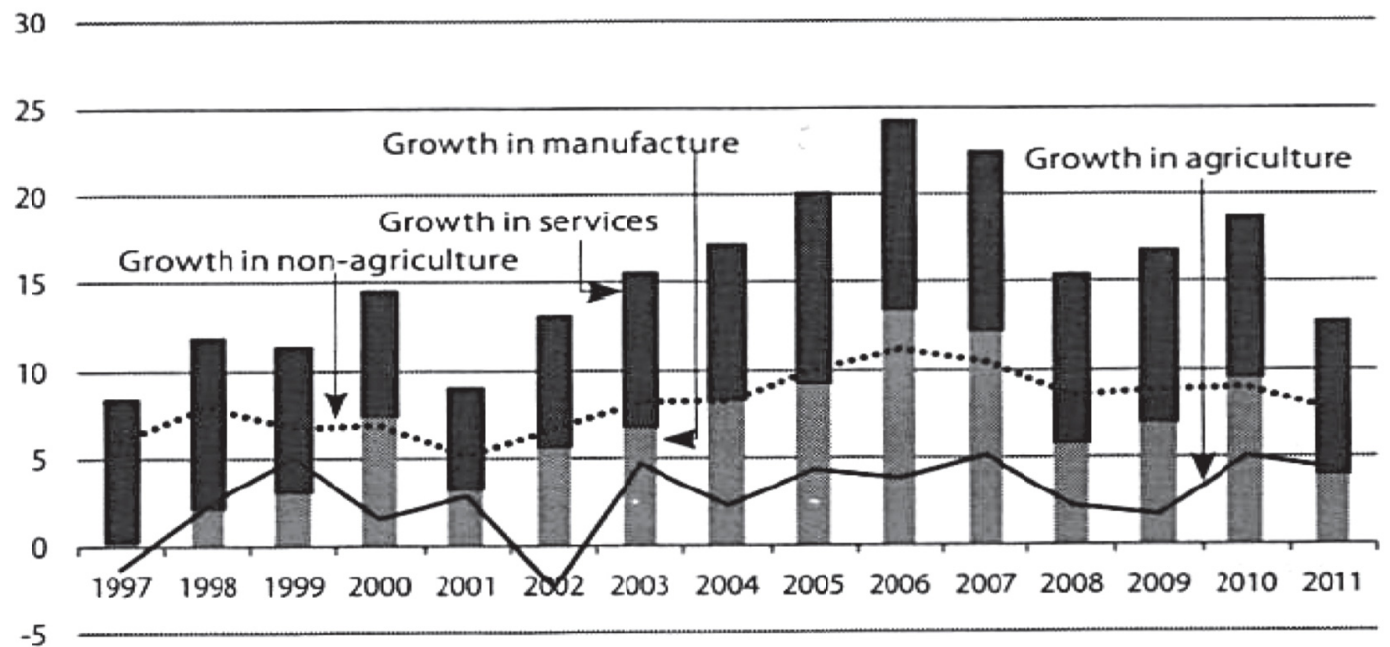

Figure 1. Sectoral growth rates in the Indian economy: manufacturing vs. non-manufacturing

Source: Economic Survey, 2014;Government of India, www.indiastats.com 
Table 1. Structure of the economy (\% of GDP)

\begin{tabular}{lccccccc}
\hline & \multicolumn{3}{c}{ India } & & \multicolumn{3}{c}{ China } \\
\cline { 2 - 3 } & 1990 & 2000 & 2010 & & 1990 & 2000 & 2010 \\
\hline Agriculture & 29.30 & 23.40 & 19.00 & & 27.10 & 15.10 & 10.10 \\
\hline Industry & 26.90 & 26.20 & 26.30 & & 41.30 & 45.90 & 46.80 \\
\hline Manufacturing & 16.70 & 16.70 & 14.20 & & 32.70 & 32.10 & 29.60 \\
\hline Services & 43.80 & 50.50 & 54.70 & & 31.50 & 39.00 & 43.10 \\
\hline
\end{tabular}

Source: World Bank (2012); the definition of manufacturing in the World Bank data set corresponds to the Standard International Trade Classification (SITCs revision 3) 5,6,7 and 8 in comtrade statistics.

Table 2. Degree of openness, value of exports and imports and \% shares of GDP and of domestic output (1990, 2000, 2010 million dollars)

\begin{tabular}{|c|c|c|c|c|c|c|}
\hline & \multicolumn{3}{|c|}{ India } & \multicolumn{3}{|c|}{ China } \\
\hline & 1990 & 2000 & 2010 & 1990 & 2000 & 2010 \\
\hline Exports of goods and services & $23,028.00$ & $61,720.00$ & $382,440.00$ & $57,374.00$ & $279,561.00$ & $1,752,600.00$ \\
\hline Exports of goods (trade) & $18,477.00$ & $44,560.00$ & $204,943.00$ & $62,091.00$ & $249,210.00$ & $1,577,932.00$ \\
\hline Exports of manufactured goods & $12,996.00$ & $34,335.00$ & $128,711.00$ & $46,205.00$ & $223,752.00$ & $1,496,162.00$ \\
\hline Exports of services & $4,551.00$ & $17,160.00$ & $177,497.00$ & na & $30,351.00$ & $174,668.00$ \\
\hline Exports of goods and services/GDP in \% & 7.25 & 13.41 & 22.14 & 16.08 & 23.33 & 29.57 \\
\hline Exports of goods/GDP in \% & 5.82 & 9.68 & 11.87 & 17.40 & 20.79 & 26.62 \\
\hline Export of manufactured goods/GDP in \% & 4.09 & 7.46 & 7.45 & 12.95 & 18.67 & 25.24 \\
\hline $\begin{array}{l}\text { Export of manufactured goods/production } \\
\text { of manufactured goods in } \%\end{array}$ & 24.51 & 47.83 & 52.48 & 39.59 & 58.16 & 85.29 \\
\hline $\begin{array}{l}\text { Exports of manufactured goods/world exports } \\
\text { of manufactured goods in } \%\end{array}$ & na & 0.69 & 1.51 & na & 4.60 & 14.23 \\
\hline Exports of services/GDP in \% & 1.43 & 3.73 & 10.28 & na & 2.53 & 2.95 \\
\hline Exports of service/production of services in \% & 3.27 & 7.38 & 18.79 & na & 6.49 & 6.84 \\
\hline Imports of goods and services & $31,485.00$ & $72,488.00$ & $465,243.00$ & $46,706.00$ & $250,688.00$ & $1,520,500.00$ \\
\hline Imports of goods (trade) & $27,914.00$ & $57,912.00$ & $346,550.00$ & $53,345.00$ & $225,097.00$ & $1,394,829.00$ \\
\hline Exports-imports of goods and services & $-8,457.00$ & $-10,768.00$ & $-82,803.00$ & $10,668.00$ & $28,873.00$ & $232,100.00$ \\
\hline Trade balance (goods) & $-9,437.00$ & $-13,352.00$ & $-141,607.00$ & $8,746.00$ & $24,113.00$ & $183,103.00$ \\
\hline Exports of goods and services + imports & $54,513.00$ & $134,208.00$ & $847,683.00$ & $104,080.00$ & $530,249.00$ & $3,273,100.00$ \\
\hline $\begin{array}{l}\text { Degree of openness (exports + imports } \\
\text { of goods and services)/GDP }\end{array}$ & 17.17 & 29.16 & 49.08 & 29.16 & 44.24 & 55.23 \\
\hline
\end{tabular}




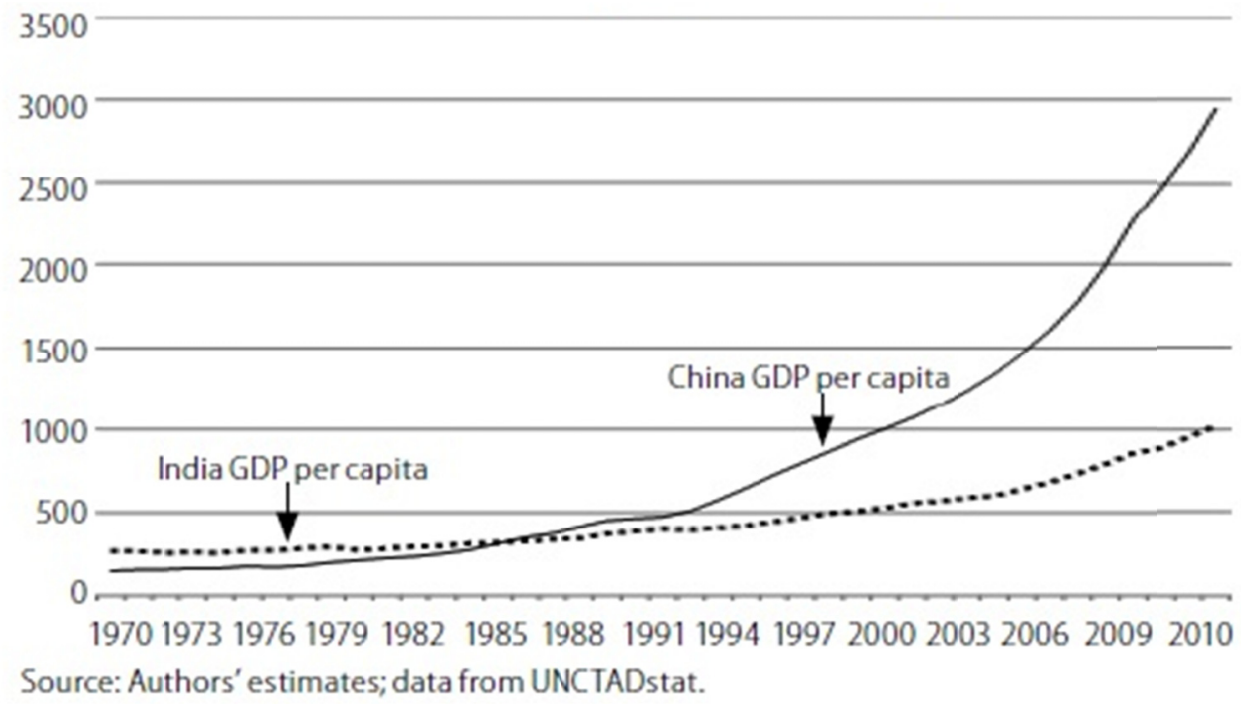

Figure 2. India and China GDP percapita, 1970-2010 (in US \$)

Table 1 shows the structure of the economy in both India and China from 1990 to 2010. Industries contributed to $26.9 \%$ to the GDP in India in 1990 , which slightly declined to $26.2 \%$ in 2000 whilst in 2010 , it rose slightly to $26.3 \%$. In contrast to this, China's industrial sector contribution was higher than that of India i.e. $41.3 \%$ in 1990, steadily rising to $45.9 \%$ and $46.8 \%$ in 2000 and 2010 . In the case of the manufacturing sector, the percentage of GDP is almost double in China as compared to that of India (see Table 1). Although exports of manufactured goods have risen in both countries between 1990 and 2010, the rate of this increase was much faster in China than in India (see Table 2). Such differences in the performance of per capita GDP terms could also be found. As Figure 1 shows, since 1990 China has witnessed a sharp rise in GDP per capita, while in India this was more modest (also see Figure 2). This was largely due to the dramatic expansion of the industrial sector and exports, while India failed to witness any similar rapid expansion in its industrial sector. At present, India's manufacturing sector accounts for $16 \%$ of the GDP and it employs about $1 \%$ of the total workforce. During the period 1990 to 2000 the annual growth of this sector has been $6.8 \%$, while for the same period China's manufacturing sector witnessed double digit growth of $12.8 \%$, which is nearly double that of India.

Here it is important to look at the industrial sectors' contribution to GDP in other developing countries such as in 1960 industries contributed 37\% of the GDP in Brazil, 45\% in China, 19\% in India, 25\% in South Korea and 19\% in Malaysia (Siddiqui, 2012b). By 1985, the figures were: $45 \%$ in Brazil, $43 \%$ in China, $26 \%$ in India, 39\% in South Korea, and 39\% in Malaysia. In 2010, industrial GDP represented 28\% in Brazil, 47\% in China, 27\% in India, 39\% in South Korea and 44\% in Malaysia.

\section{State vs. Market in Fostering Industrialisation}

It is important to examine the choices in industrial policy between the role of state and market. The development of modern industries has been subject to debate among academics and policy makers, concerning whether industrial strategy should be based on 'import-substitution' or 'export-led growth'. In the neoclassical model, the role of the state should be minimal, whilst greater reliance is placed on "market forces" (Basu and Maertens, 2007; Krueger, 1987). The neo-classical economists advocate for the minimal role of the state in the development of the industrial sector and they largely focus on 'getting the price right' (Krueger, 1987). Such arguments run into difficulties when there is virtually no past evidence to support this model of development. Successful industrialisation in the past was always carried out with active state intervention whenever it was seen necessary in order to achieve suitable outcomes (Reinert, 2007).

However, historical experience for developed countries clearly shows us that state intervention is important to promote industrialisation. For example, in the $19^{\text {th }}$ century the United States had extensive policies in favour of protectionism. Britain also adopted protectionist measures and used state intervention to promote its industrial sector. In the $18^{\text {th }}$ century British policy was characterised by heavy tariffs to protect its domestic industries against the onslaught of cheap foreign goods. Britain had heavy tariffs from 1775 onwards, which continued for a century. The 
British government levied export duties, which made raw wool more expensive to foreign producers; at the same time it provided tax exemption and monopolies to those who established themselves as wool manufacturers. This continued for nearly a century, followed by a ban on all export of woollen cloth from Ireland from 1699 onwards. The suppression of Ireland's domestic woollen industry was seen as necessary in order to build wool manufacturing in England (Girdner and Siddiqui, 2008). The Western countries who today support the free market, in the past saw the active role of the state as essential to achieving desired levels of growth and building a strong industrial sector (Chang, 2010).

Thus, historical evidence concerning successful industrialisation confirms that building an industrial base in the developing countries would require state support, which would also put a limit on imports ((Siddiqui, 2012a). Otherwise the nation in question would be trapped into focusing on exports of raw material and low value products as is the case for the majority of the developing countries, a sector that is characterised by diminishing returns and often over-supply and negative terms of trade. In a broader historical context, Rist argues that, "The historical conditions that would explain the 'lead' of some countries over others cannot enter into the argument, since the 'laws of development' are supposedly the same for all, and 'win their way through with iron necessity' [...] this bracket out the effects of conquest, colonisation, the slave trade, the dismantling of craft production in India, the breaking of social structures, and so on" (Rist, 2009:75).

Therefore, discussion of past experiences is important. In order to achieve industrialisation, the question arises whether reliance should be made on state intervention or market forces in the economy. The Prebisch-Singer model argues that government intervention is seen as crucial for successful industrialisation since according to them this would lead to diversification of the economy and output. This is considered a necessary prerequisite for affluence. As a consequence, not only failed to diversify their economy but also unable to draw people away from agriculture into expanding manufacturing sector flourished. Higher growth in the manufacturing sector could lead to higher productivity not only in agriculture but also other industries as well. It has been argued that negative trends in terms of trade acts as an impediment to the economic progress of the developing countries (Singer, 1987).

However, the past experiences of Brazil, China, India and Mexico tell us that the 'import substitution' policy ran into difficulties after some time (Siddiqui, 2015b) This was due to a number of reasons like in the name of protection of domestic markets: inefficiency, rent-seeking, and wastefulness of resources flourished. Local producers turned into monopolies and thus were able to charge higher prices than imported prices.

\section{Concluding Remarks}

If we consider the $20^{\text {th }}$ century as a whole then the key turning point in terms of industrial development came in 1950, soon after India's independence, not in 1991 as is often portrayed. However, it is true that India has proved unable to transform high growth over economic development and general improvement in living conditions for ordinary people. In the 1970s, the perception was that India's industrial policies were wrong, mainly due to two reasons: the slowdown in growth rates and the persistent success of East Asian economies in terms of both higher growth rates and improvements in living conditions.

It was said that the 'import substitution' strategy to protect domestic industries led to high costs, inefficiency and low growth in the economy. Further it is argued that such policies stifled competition, build 'licence raj' and suffocated entrepreneurship and undermined initiative in the private sector.

The neoliberal reforms of 1991 in India removed tariffs and barriers to foreign trade and investment. They reduced the role of the state and public sector, and dismantled controls, while increasing the role of the market and the private sector in the economy. As a result, foreign capital investment and foreign exchange reserves have improved. However, job expansion has not taken place and there has been no corresponding decline in the share of agricultural employment. Even the much heralded IT sector's dramatic expansion for the last two decades provided jobs directly to less than a million people.

There has often been talk in recent years of making India a base for labour intensive manufacturing, as Chinese wages are rising. It would be misleading to think a large country like India could industrialise and modernise its economy with the existing unequal distribution of land and rural assets, with such low investment on education and health sector.

Finally, since 1991 there have been considerable shifts in economic policy towards a greater reliance on market forces and a more limited degree of government intervention in the economy. However, it is evident that largely relying on market-based growth cannot meet the severe challenges India is currently facing, most notably from persistent economic and social deprivation. This study has found that more than two decades have passed since the 
neoliberal reforms were launched, but industrial growth has still not witnessed rapid expansion, especially in manufacturing areas. And it seems that neoliberal policies have failed to create jobs and thus improve the living conditions of significant proportion of the population, which will most likely impose ever greater constraints on the economic growth itself. Therefore, to combat these problems certainly requires effective government policy intervention, especially in areas such as education and health sectors, which could ultimately have very positive effects on industrial growth and productivity.

\section{Acknowledgements}

The author have benefitted from discussions on this issue with R.K. Barik and D.P. Tripath. The author is also indebted to Barry Pavier and Anne White for helpful comments and suggestions on earlier version. Also would like to thank anonymous referee for helpful comments.

\section{References}

Amsden, A. (2003). The Rise of "The Rest" - Challenges to the West from the Late Industrialising Economies. London: Oxford University Press.

Anstey, V. (1957). The Economic Development of India. London: Longmans Green and Co.

Bagchi, A.K. (1976). De-industrialisation in India in the $19^{\text {th }}$ Century: Some Theoretical Implications. Journal of Development Studies, 12(2), 135-164.

Bagchi, A.K. (1985). The Political Economy of Underdevelopment. London: Cambridge University Press.

Basu, K., \& Maertens, A. (2007). The Patternsand Causes of Economic Growth. Oxford Review of Economic Policy, 23(2), 143-167. http://dx.doi.org/10.1093/oxrep/grm012

Bhaduri, A. (1993). Orthodox Development Theories and their Application to Less-Developed Countries. In Gianni Vaggi (Ed.), From Debt Crisis to Sustainable Development: Changing Perspectives in North-SouthRelationship. London: St. Martin's Press.

Central Statistical Organisation (CSO). (2014). National Accounts Statistics of India. New Delhi, Government of India. Retrieved from mospi.nic.in/Mospi_New/site/inner.aspx?status $=2 \&$ menu_id $=92$

Chang, H.J. (2010). Bad Samaritans: The Myth of Free Trade and the Secret History of Capitalism. London: Bloomsbury Publishing.

Das, G. (2006). The India Model. Foreign Affairs, 85(4), 2-16. Retrieved from https://www.foreignaffairs.com/articles/asia/2006-07-01/india-model

Dutt, R.C. (1902). Economic History of India under early British Rule, Vol. 1. London: Kegan Paul.

Economic Survey. (2010). Government of India, New Delhi: Ministry of Finance. Retrieved from www.indiastats.com

Economic Survey. (2014). Government of India, New Delhi. Retrieved from www.indiastats.com

Girdner, E.J., \& Siddiqui, K. (2008, Jan.-June). Neoliberal Globalization, Poverty Creation and Environmental Degradation in Developing Countries. International Journal of Environment and Development, 5(1), 1-27.

Government of India. (2006-07). Agricultural Statistics at a Glance. New Delhi: Ministry of Agriculture.

Habib, I. (1975). Colonisation of Indian Economy, 1757-1900. Social Scientist, 3(8).

Habib, I. (1984, December). Studying a Colonial Economy Without Perceiving Colonialism. Social Scientist, 5-27.

Kaldor, N. (1967). Strategic Factors in Economic Development. Ithaca, New York: Cornell University Press.

Kalecki, M. (1971, February). Class Struggle and the Distribution of National Income. Kyklos, 24(1), 1-9. http://dx.doi.org/10.1111/j.1467-6435.1971.tb00148.x

Krueger, A. (1987). Rent Seeking. In Eatwell, J, Milgate, M. and Newman, P. (Eds.), The New Palgrave: a dictionary of economics (Vol. 4, pp.147-149). London: Macmillan.

Lewis, A.W. (1954, May). Economic Development with Unlimited Supplies of Labour, 22(2), 400-451. Manchester School, UK.

Maddison, A. (1995). Monitoring the World Economy, 1820-1992. Development Centre of the OECD, Paris: OECD. Nagaraj, R. (2006). Aspects of India's Economic Growth and Reforms. New Delhi, Academic Foundation. 
Nayyar, D. (2006). Economic Growth in Independent India: Lumbering Elephant or Running Tiger. Economic and Political Weekly, $15^{\text {th }}$ April, 1451-1458.

Panagariya, A. (2004). Growth and Reforms during the 1980s and 1990s. Economic and Political Weekly, $19^{\text {th } J u n e, ~}$ 2581-94.

Patnaik, P. (1979, June). Industrial Development in India since Independence. Social Scientist, 7(11), 3-19

Raj, K.N. (1986). Growth and Stagnation in Indian Industrial Development. Economic and Political Weekly, XXI(5-7), February, Annual Number.

Reinert, E. (2007). How the Rich Countries got Rich and Why Poor Country Stay Poor. New York: Carroll \& Graf.

Rist, G. (2009). The History of Development ( $3^{\text {rd }}$ ed.). New Delhi: Academic Foundation.

Sen, P. (2007). Capital Inflows, Financial Repression, and Macroeconomic Policy in India since the Reforms. Oxford Review of Economic Policy, 23(2), 292-310.

Siddiqui, K. (1990). Historical Roots of Mass Poverty in India. In Thayer, C.A. et al. (Eds.), Trends and Strains (pp.50-76). New Delhi: Continental Publishing House.

Siddiqui, K. (1991). Recent Neoliberal Economic Reforms in India. Information, (in Danish), 19 ${ }^{\text {th }}$, September, Copenhagen, Denmark.

Siddiqui, K. (1996, January). Growth of Modern Industries under Colonial Regime: Industrial Development in British India between 1900 and 1946. Pakistan Journal of History and Culture, 17(1), 11-59.

Siddiqui, K. (1998). The Export of Agricultural Commodities, Poverty and Ecological Crisis: A Case Study of Central American Countries. Economic and Political Weekly, 33(39), $26^{\text {th }}$ September, A128-A137.

Siddiqui, K. (2009, March). The Political Economy of Growth in China and India. Journal of Asian Public Policy, $1(2), 17-35$.

Siddiqui, K. (2010). The Political Economy of Development in Singapore. Research in Applied Economics, 2(2), 1-31. http://dx.doi.org/10.5296/rae.v2i2.524

Siddiqui, K. (2012a, December). Developing Countries Experience with Neoliberalism and Globalisation. Research in Applied Economics, 4(4), 12-37. http://dx.doi.org/10.5296/rae.v4i4.2878

Siddiqui, K. (2012b, November). Malaysia's Socio-Economic Transformation in Historical Perspective. International Journal of Business and General Management, 1(2), 21-50.

Siddiqui, K. (2013, December). Experiences of Developmental State in India and Taiwan. Think India Quarterly, 16(4), 91-121.

Siddiqui, K. (2014a). Contradictions in Development: Growth and Crisis in Indian Economy. Economic and Regional Studies, 7(3), 82-98.

Siddiqui, K. (2014b). Modernisation and Displacement of Rural Communities in India. Journal of Social Business, $4(2-3), 3-27$.

Siddiqui, K. (2015a). Agrarian Crisis and Transformation in India. Journal of Economics and Political Economy, 2(1), 3-22.

Siddiqui, K. (2015b). Perils and Challenges of Chinese Economic Development. International Journal of Social and Economic Research, 5(1), 1-56. http://dx.doi.org/10.5958/2249-6270.2015.00001.X

Singer, H.W. (1987). The Terms of Trade and Economic Development. In Eatwell, J, Milgate, M. and Newman, P. (Eds.), The New Palgrave: a dictionary of economics (Vol. 4, pp.626-628). London: Macmillan.

Srinivasan, T.N. (2005). Comments on from Hindu Growth to Productivity Surge: The mysteries of Indian growth transition. IMF Staff Papers, 52(2), Washington DC: IMF.

The Economist. (2007). India on Fire. $1^{\text {st }}$ February, London.

Thorner, D. (1962). De-industrialisation in India 1881-1931. In Thorner, D. and Thorner, A. (Eds.), Land and Labour in India. Bombay: Asia Publishing House.

UNCTAD. (2013). Trade and Development Report. New York: United Nations.

World Bank. (2006). India's Employment Challenges. Washington DC, The World Bank. 